\title{
The Effect of Drilling Method Towards Overhand Passing Ability
}

\author{
Desi Tri Susanti, Ishak, Hermamzoni \\ Sports Training Program of Sports Science Faculty \\ Universitas Negeri Padang \\ Jl. Prof Dr. Hamka, Air Tawar Barat, Padang \\ Email: del2susanti@gmail.com
}

\begin{abstract}
This study aimed to measure the effect of the drilling method towards the overhand passing ability of the athletes of the Mangga Dua volleyball club in Lintau Buo District. This was a quasi-experimental study that involved 13 female athletes. The instrument of the research was the Repeated Volleys test. The normality test and t-test were used as a statistical technique of data analysis. The collected data were used to test the hypothesis of this research by using a t-test analysis. Previously, the normality test was conducted as a test analysis requirement. The result of t-test shows that the $t_{\text {count }}$ was 3.43 and $t_{\text {table }}$ was $1.78\left(t_{\text {count }}=3.43>\right.$ $t_{\text {table }}=1.78$ ). Thus, there was a significant effect of the drilling method towards the overhand passing ability of Mangga Dua volleyball club's athletes in the Lintau Buo District.
\end{abstract}

Keywords -dribbling method, overhand passing

\section{INTRODUCTION}

One of the sports that received attention and coaching today is the sport of the team Bolavoli. Perkembangan Sports Bolavoli in Su-Matera West is already very community. This is evidenced that there are already many clubs whose spread has covered the Regency/city and in the region of West Sumatera. Bolavoli is one of the sports branches from the United States of America, so that all terms both technical and non-technical are dominated by the use of English.

Bolavoli is one of the many popular sports branches in society. It was evident that Bolavoli was widely played Disekolah-sekolah, Ka-ntor-Office, city, and village. Bolavoli is a branch of sports games that have been known from the ages of children to the de-wasa of both men and the lessons. This is in accordance with the opinion [1] stating that, "The game Bolavoli is one of the sports CA-Yarakat in the world, both as a sport of matches and school sports and Recreation".

One of Bolavoli's special achievement containers in West Sumatera is the Bolavoli club Mangga Dua, Lintau Buo Sub-district, has been conducting coaching for the Bolavoli athletes and has also created athletes who are in the national and West Sumatera level. Therefore, the expected construction of the Mangga Dua Volleyball Club in Lintau Buo Sub-district can build and train and produce athletes who have the wisdom and achievement in the sport of Bolavoli.
[2] explaining that: "Sports achievement is a sport that builds and develops sportsmen in a planned, level, and sustainable manner through competitions to achieve the press-through with the support of science and technology. Sports ".

Based on the quotation, to achieve achievement in the sport should be done in a planned, level, sustainable with the science and technology of sports.

To improve the achievement of the branch Bolavoli there are four Kom-ponents that must be considered; Physical, technical, tactics and mental conditions. This corresponds to the one presented by Zimmermann in [3] which is: "The achievement shown by athletes, both individually and in groups (teams) in a match is a mixture of physical abilities, tech-Nik, tactics and skills Those athletes have ". Based on the opinion of the expert, in the development of sports performance, it is necessary for good work, not only in physical coaching, tactics, or strategies, but also requires coaching from psychological aspects or mental (psychic) aspects.

Based on the explanation above, the aspect of soul and body is a unity of mutual mempe-ngaruhi. In other words, that any human behaviour or behavior will not be detached from the influence of the soul and physical aspects or the physic and psychological aspects. Therefore, everything that is felt or experienced by heinous will also be felt by the body. Next to achieve achievements in the sport, the construction is done in a faceted aspect.

Based on the statement of the experts above, to achieve achievement in the field of sports in Bolavoli, construction is dilak on various aspects that will affect the development of achievements such as physical abilities, coaching tactics and stra-Tegi, and infrastructure, engineering development, pro-fesional trainers, good management and athletes with Personality corresponding to the sports branch of Bolavoli.

Construction with the sports development is already in the sidelines we give special attention, so from the achievement in-expected to be review by conducting research in the field of sport, especially volleyball. The game of Bolavoli is to insert the ball of the opponent through a Rin-hand in the form of a rope or net and try to win the play by turning off the ball in the opposite area [4]. In the game of Bolavoli there are some basic techniques that must be mastered. According to [5] "The 
techniques in per-toy Bolavoli consist of service, passing down, passing, block, and smash".

Any trainer in Memberi-kan exercise should use exercise methods. In principle the method is the way or all activities that are taken up to be used in reaching the objectives. Remembering each exercise method has its limitations of kindness and weakness. The better the exercise method is even more effective in achieving the objectives. The method of playing practice is a method of practice that researchers expect to know whether it is effective or not to increase the kemam-puan of the kickpassing of the club Bolavoli Mangga Dua subdistrict LinTau Buo. From the results of this study was expected to be born a symbolation that can be used as an anticipatory step for the increase of Kemam-puan passing the head to the front.Passing over Passing over is the most important element in the game Bolavoli. Without this technique, a meaningful attack was made, according to [1] stating that "The Umpah is presenting the ball to a friend in a team which then the ball can be spread to the area Field opponent players in the form of smash ". So it is obvious that the top pass is an important technique for players to master, as this technique is a decisive part in the wake of the attack. The technique of feeding is essentially the same as the underpassing technique, located the difference only on the goal and kurve the way of the ball. The feeding technique can be done well with the passing or the bottom passing. However, if it is reviewed in terms of the implementation, it will be completed if the technique of mengum-pan is done with the technique of passing over, because it will further ensure the accuracy of the target when compared to the technique passing down. As for the good bait is: "(1) the ball should soar calmly in the area of attack on the field itself, (2) the ball must be on the net with sufficient height for easy in the smash by SMAs-Her, (3) road bait with net according to the type of attack Desired ". [4].

According to [6] "passing over can be differentiated over four kinds: 1) passing over forward, 2) passing on down, 3) passing on short, 4) passing over falling". Reactions, and exercise ex-plosive power (explosive power).

\section{Play Practice Methods}

Exercise is a major key in sports performance, according to [3] la-Eness is "a process of practice or application of training materials such as movement-skills in the form of repeated performances and through demands that Variations ". The meaning of the terms of the method by the wider community has been interpreted as diverse, which sometimes the meaning is different. The method derived from the English "met-hod" means it is a way or a path to work on something. The meaning of the play is "an activity that the children would enjoy to bring joy". The method of playing practice that the player intent in this study is the stacking of the top passing exercises in such a way consist of five forms of exercise passing over the athlete Club Bolavoli Mangga Dua District Lin-Tau Buo.

\section{RESEARCH METHODS}

Based on the problems studied, this type of research is a pseudo experiment (Quasi Experimen-tal). In order for this research to be more directed, it must be specified population and samples as objects and subjects that will conduct research. The Po-pulation and samples that researchers select in conducting the following research: The population in this study was the athlete of the club Bolavoli Mangga Dua District Lintau Buo which amounted to 29 people with 16 sons and 13 daughters. The technique of making SAM-mop to be done in a penElitian is purposive samp-ling technique. The researchers sampled 13 people, women athletes aged 15 years and over.

The instrument to be used to disclose the data in this PE-nelitian form Repeated Volley Validity Test of 0.80 and a re-ability test of 0.87 . Prior to Melaku-kan tests, the first prepared measures, the tools of collection of the DA-TA, training programs, helper Pelak-sanaan tests, the implementation of tests as well as matters relating to the Pengum and data retrieval. In order to obtain the data in this study, two Tests were conducted, namely the preliminary test and the final Test in the athlete as a sample.

A. Preliminary test Preliminary tests are tests conducted prior to the treatment of the Kemam-puan passing test, conducting a top pass to the target with a specified distance of 30 seconds.

\section{B. Final Test}

After the giving of LA-eness load for 16 times the meeting to all SAM-mop, then done Pengu-Kuran final test of the ability to increase Pas-sing on athletes club Bolavoli Mangga Dua District Lin-Tau Buo. With the same time (30 seconds). After obtaining the required data then proceed with analyzing the data. The Data obtained is processed and analyzed according to research objectives and questions. The data on the results of the Pene-Litian is aimed at testing the correctness of the hypothesis proposed in a study. The data analysis technique used in this research is Test $\mathrm{T}$. Before conducting $t$ test, the analysis requirement of NORmalitas test.

\section{RESULTS AND DISCUSSIONS}

The ability to pass the top of the play exercise method-has not been given the TERHA-DAP treatment of the sample, carried out an initial test of passing ability with the acquisition of a wide number of pati. In the initial test of 13 people samples were obtained the highest passing number is 29 Passingan, and the lowest number of kicks is 18 Passingan. After being given a treatment of 13 people SAM-mop with exercise method of playing according to the exercise program. The latter is carried out the final Test (post test) to be passed on with the following PE-Rolehan passing. Passing over the highest 34 Pati, the lowest passing number of 21 Pati. 


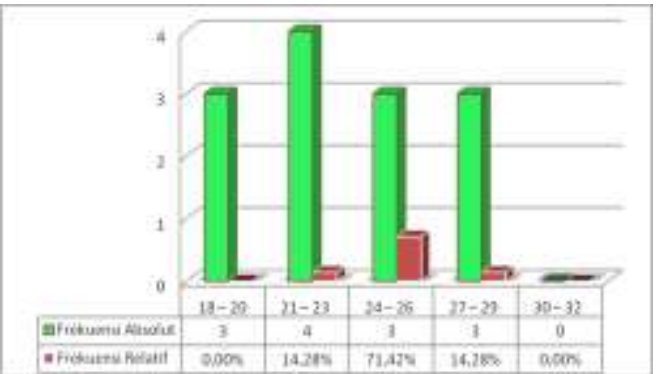

Figure 1. Histogram Results Pre test ability Passing over

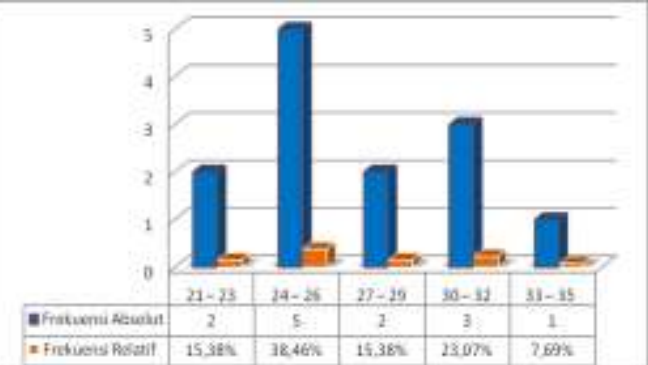

Figure 2. Histogram result post test ability Passing over Based on the distribution table of Fre-kuensi above for data pree test, obtained results from 13 people samples, 3 people $(23.07 \%)$ Range between $(18-20), 4$ people $(30.76 \%)$ Range between $(21-23), 3$ persons $(23.07 \%)$ Range between $(24-26), 3$ persons (23.07\%) Range between (27-29), 0 ranges between (30-32). And for Post Test results obtained results from 13 people samples, 2 to Range (15.38) between the (21-23), 5 people $(38.46 \%)$ Range between $(24$ - 26), 2 persons (15.38\%) Range between $(27-29), 3$ persons $(23.07 \%)$ Range between (30 - 32), 1 person (7.69\%) Range between (33-35). Here it looks that the athlete's Pas-sing ability is not the same before and after given the play exercise method. It is based on the turnover of the calculated to-the top of the athlete's passing on the initial test is 23 times while the average acquisition of the ability to pass the athlete on the final Test after performing exercise method of play practice is 27 times, meaning it happens Added to-the accuracy of passing over the average 4 times the distraction.

Prior to being done by the hypotheses proposed, the test data analysis requirement was conducted to test the normality of each data from the variables. Test data normality from variable-va-Riabel is done by using liliefors test. The test results of normality for data pre test group samples given the treatment method of play exercise acquired score Lo $=0.1095$ with $\mathrm{n}=13$, and Ltab in the level of testing sig--so $\alpha=0.05$ obtained 0.234 larger than Lo. So that it can be inferred by the ability to pass the results of the pre test exercise method of the Beermain exercise is derived from the population with a normal distribution.

Furthermore, the results of the normality for the postpractice sample data given per-do weight training Mengguna-kan the weight of the foot obtained a score of Lo $=0.103$ with $\mathrm{n}=13$, and Ltab on a significant Test level $\alpha=0.05$ gained 0.234 larger of Lo. So that it can be concluded that the data of ability to pass the post test result of the play exercise method comes from a population with a normal distribution.
The proposed hypothesis is that there is a significant influence from the method of practice of playing against the to-be passing over the athletes of the Mangga Dua Volleyball Club District Lintau Buo. Based on the comparison analysis with the formula (Test T) performed then the results of analysis (Test $\mathrm{T}$ ) as follows

Table 1. Summary results (Test T) Exercise method of play

\begin{tabular}{|c|c|c|c|}
\hline $\begin{array}{c}\mathbf{D f}= \\
(\mathbf{N}-\mathbf{1})\end{array}$ & thitung & $\begin{array}{c}\text { ttabel } \\
\boldsymbol{\alpha}=\mathbf{0 , 0 5}\end{array}$ & Conclusion \\
\hline 13 & 3,43 & 1,78 & Signifikan \\
\hline
\end{tabular}

The results of the T-Test analysis stated there was a significant influence of the play Practice Method (X) on the passing of (Y) Athletes Club Bolavoli Mangga Dua subdistrict Lintau Buo. This is based on the results of T-Test analysis, where it is obtained th $=3.43>$ This $=$ 1.78 at the significance of $\alpha=0.05$ then it can be concluded that there is a significant influence of the method Mangga Dua subdistrict Lintau Buo.

The discussion in this exercise is based on theoretical studies and statistical calculations, referring to the conclusion on the analysis that has been done, then the discussion will be conducted. In this discussion, will refer to the HiPo-thesis proposed in the study. The influence of exercise methods to be able to fit the ability of Pas-sing over the club Bolavoli Mangga Dua District Lintau Buo.

Based on the results of Peneli-tian done in the field of playing practice methods to improve the ability of Passing over the club Bolavoli Mangga Dua Lintau Buo to get the overall results of the research in view of the results table post test ability Passing the club Bolavoli Mangga Dua Ke-Camatan Lintau Buo with a mean of 21.

Based on the findings, it can be concluded that there is a significant influence on the play exercise method on the ability to pass. That exercise by using the method of playing exercises can be applied in the ability to improve the passing. To achieve good achievement, one needs to go through a long training process programmatically, systematically, directed and continuous according to the sport. The training process is a series of physical and psychic (mental) activities that are done by athletes under the trainer BIM-Bingan for the purpose of enhancing and maintaining the achievement of athletes. So, by doing the practice method of playing programmatically will be able to make the ability to pass the top. Passing over is the most important element in the per-toy Bolavoli. Without this technique, there is no meaningful attack, the top pass is one of the techniques of Gumpan, according to [1] stating it is "presenting the ball to a friend in a team that then the ball can be spread to the area Field opponent players in the form of smash ". So it is obvious that the top pass is an important technique for players to master, as this technique is a decisive part in the wake of the attack. The technique of feeding is essentially the same as the underpassing technique, located the difference only on the goal and kurve the way of the ball. The technique 
of collecting the gumming can be done well with the passing or the bottom passing. But if it is reviewed in terms of the implementation it would be beneficial if the technique of feeding it is done with the technique of passing over, because it will further guarantee the accuracy of the target when compared with the technique of lower passing. As for the good bait is: "(1) the ball should soar calmly in the area of attack on the field itself, (2) the ball must be on the net with sufficient height for easy in smash by Smasher, (3) road bait with net according to the type of attack Desired ". [4]. According to [6] the passing of the top can be distinguished by four kinds: 1) passing over to the front, 2) passing down, 3) passing over the short, 4) passing over the falling. From the above analysis of the results of an-alisis can also be concluded that there is influence of the method of LatiHan play which means against the ability to pass the capacity of the club Bolavoli Mangga Dua District Lintau Buo. The training is programmatic and continous, the more often we do the exercise method Berma-in passing over, it will be a bush-in either to influence the camp passing by someone, what is again in the moment to build attacks, both in action and reaction in the Doing a BALasan and attacking. Not regardless of the results obtained in this study, the related factors of the exercise process also greatly affects the results achieved, such as intensity, duration, volume, frequency and intervals in the Lati-Han itself. Because each of these factors contributes to the continuity of the programmatic Lati-Han.

Thus it is obvious that the method of playing practice given can increase the ability to pass top athletes Club Bolavoli Mangga Dua District Lintau Buo with the application of exercises not regardless of intensity, volume, and the training fre-Kuensi. If the method of playing practice is not given to the athlete of the club Bolavoli Ma-Ngga two sub-district Lintau Buo, then the ability to pass-over owned will not have any improvement. De-mikian is also the opposite, when the intensity, volume and frequency of the play exercise method is dited, then the improvement to the player's passing over the athlete will also be better.

\section{CONCLUSIONS}

Based on the results of the researchers and the hypothesis testing, it can be concluded that exercise methods of playing practice can improve the ability of the passing. Thus it can be vertices that exercise method of practice of playing can increase the Kemam-puan Passing the athlete Club Bolavoli Mangga Dua District Lintau Buo.

According to the conclusion and the results of the above research, then can be put forth some advice as follows: 1) for coaches, the form of exercise method of practice play is a form of exercise that can increase to-be able to pass over. 2) Athlete-Volleyball is advised to perform the LatiHan method of playing exercises seriously and sincerely so that the Lati-do more effective and beneficial to improve the maximum passing of the top, and later will add In the competition. 3) Each training form is Digunakan, it is worth noting the procedure of practice exercise so as not to happen in the exercise so that the training objectives can be achieved well. 4) It is hoped that another study could see several factors that have not been noticed in this study.

\section{REFERENCES}

[1] Bachtiar. "Pengetahuan Dasar Permainan Bolavoli”. Padang: FIK UNP. 2000, pp 30.

[2] Undang-Undang Negara Republik Indonesia Nomor 3 (2005) Sis-tem Keolahragaan Nasional. Bandung: Citra Umbara. 2005, pp 45.

[3] Syafruddin. "Ilmu Kepelatih-an Olahraga". Padang: UNP. 2012, pp 37.

[4] M. Yunus. "Olahraga PILIHAN Bolavoli". Jakarta: Depdikbud. 2000, pp 25.

[5] N. Ahmad. "Panduan Olahraga Bolavoli". Surakarta: Era Pustaka Utama. 2007, pp. 12.

[6] G. Blume. "Permainan Bolavoli (Pelatihan Teknik-Taktik)". Padang: FIK UNP. 2004, pp. 35 . 